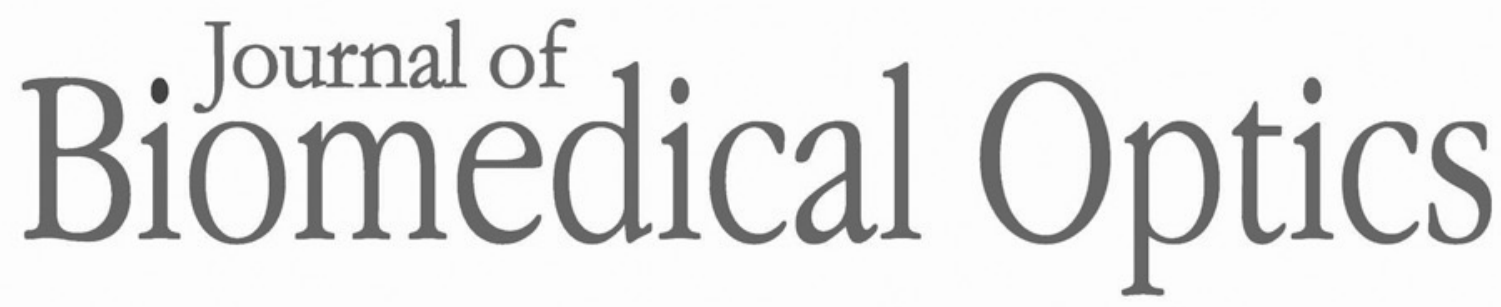

BiomedicalOptics.SPIEDigitalLibrary.org

\title{
Continued Growth of JBO
}

\author{
Lihong V. Wang
}

\section{SPIE.}




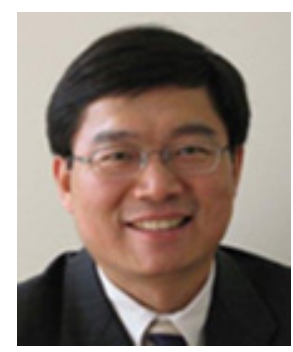

\section{Continued Growth of JBO}

JBO sustained its healthy growth in 2012. The number of manuscript submissions increased by $5 \%$ to 788 . JBO's success is attributed to the contributions of the authors, reviewers, guest editors, and editorial board members.

The following authors contributed invaluable review articles, which have been granted online open access by SPIE immediately upon publication:

1. N. J. Crane and E. A. Elster, "Vibrational spectroscopy: a tool being developed for the noninvasive monitoring of wound healing," J. Biomed. Opt. 17(1), 010902 (2012).

2. G. Q. Yu, "Near-infrared diffuse correlation spectroscopy in cancer diagnosis and therapy monitoring," J. Biomed. Opt. 17(1), 010901 (2012).

3. S. G. Resink, A. C. Boccara, and W. Steenbergen, "State-of-the art of acousto-optic sensing and imaging of turbid media," J. Biomed. Opt. 17(4), 040901 (2012).

4. B. Cox, J. G. Laufer, S. R. Arridge, and P. C. Beard, "Quantitative spectroscopic photoacoustic imaging: a review," J. Biomed. Opt. 17(6), 061202 (2012).

5. P. C. Pearlman, A. Adams, S. G. Elias, W. Mali, M. A. Viergever, and J. P. W. Pluim, "Mono- and multimodal registration of optical breast images," J. Biomed. Opt. 17(8), 080901 (2012).

6. T. Lister, P. A. Wright, and P. H. Chappell, "Optical properties of human skin," J. Biomed. Opt. 17(9), 090901 (2012).

The following authors are to be congratulated on earning the top 10 most cited papers among the JBO papers published in 2011, as of this writing:

1. T. Meyer, N. Bergner, C. Bielecki, C. Krafft, D. Akimov, B. F. M. Romeike, R. Reichart, R. Kalff, B. Dietzek, and J. Popp, "Nonlinear microscopy, infrared, and Raman microspectroscopy for brain tumor analysis," J. Biomed. Opt. 16(2), 021113 (2011).
2. J. J. Yao, K. I. Maslov, Y. Zhang, Y. N. Xia, and L. V. Wang, "Label-free oxygen-metabolic photoacoustic microscopy in vivo," J. Biomed. Opt. 16(7), 076003 (2011).

3. B. Kemper, A. Vollmer, C. E. Rommel, J. Schnekenburger, and G. von Bally, "Simplified approach for quantitative digital holographic phase contrast imaging of living cells," J. Biomed. Opt. 16(2), 026014 (2011).

4. A. C. van Leeuwen, T. Buckle, G. Bendle, L. Vermeeren, R. V. Olmos, H. G. van de Poel, and F. W. B. van Leeuwen, "Tracer-cocktail injections for combined pre- and intraoperative multimodal imaging of lymph nodes in a spontaneous mouse prostate tumor model," J. Biomed. Opt. 16(1), 016004 (2011).

5. D. Kobat, N. G. Horton, and C. Xu, "In vivo twophoton microscopy to $1.6-\mathrm{mm}$ depth in mouse cortex," J. Biomed. Opt. 16(10), 106014 (2011).

6. M. S. Bergholt, W. Zheng, K. Lin, K. Y. Ho, M. Teh, K. G. Yeoh, J. B. Y. So, and Z. W. Huang, "Characterizing variability in in vivo Raman spectra of different anatomical locations in the upper gastrointestinal tract toward cancer detection," J. Biomed. Opt. 16(3), 037003 (2011).

7. N. J. Durr, C. T. Weisspfennig, B. A. Holfeld, and A. Ben-Yakar, "Maximum imaging depth of twophoton autofluorescence microscopy in epithelial tissues," J. Biomed. Opt. 16(2), 026008 (2011).

8. B. C. Quirk, R. A. McLaughlin, A. Curatolo, R. W. Kirk, P. B. Noble, and D. D. Sampson, "In situ imaging of lung alveoli with an optical coherence tomography needle probe," J. Biomed. Opt. 16(3), 036009 (2011).

9. R. K. K. Wang and L. An, "Multifunctional imaging of human retina and choroid with 1050-nm spectral domain optical coherence tomography at $92-\mathrm{kHz}$ line scan rate," J. Biomed. Opt. 16(5), 050503 (2011).

10. N. T. Shaked, L. L. Satterwhite, M. J. Telen, G. A. Truskey, and A. Wax, "Quantitative microscopy and nanoscopy of sickle red blood cells 
performed by wide field digital interferometry," J. Biomed. Opt. 16(3), 030506 (2011).

I thank the following guest editors for their tireless efforts in editing the following special sections:

1. A. Periasamy, S. S. Vogel, and R. M. Clegg, "Special Section Guest Editorial: FRET at 65: a celebration of Forster," J. Biomed. Opt. 17(1), 011001 (2012).

2. X. D. Li and W. S. Grundfest, "Special Section Guest Editorial: Endomicroscopy technologies and biomedical applications," J. Biomed. Opt. 17(2), 021101 (2012).

3. M. A. Anastasio and P. C. Beard, "Special Section Guest Editorial: Photoacoustic imaging and sensing," J. Biomed. Opt. 17(6), 061201 (2012).

4. S. Andersson-Engels and P. E. Andersen, "Special Section Guest Editorial: Selected topics in biophotonics: optical coherence tomography and medical imaging using diffuse optics," J. Biomed. Opt. 17(7), 071301 (2012).

5. A. Gandjbakhche, J. M. Kainerstorfer, and B. Tromberg, "Special Section Guest Editorial: Optical diagnostic and biophotonic methods from bench to bedside," J. Biomed. Opt. 17(8), 081401 (2012).

6. E. Borisova, H. Schneckenburger, and A. Priezzhev, "Special Section Guest Editorial: Laser technologies for biomedical applications," J. Biomed. Opt. 17(10), 101501 (2012).

The following guest editorial board members diligently managed the most manuscript reviews behind the scenes in 2012:

1. Eric Potma, University of California, Irvine, USA

2. Gabriel Popescu, University of Illinois at UrbanaChampaign, USA

3. Milind Rajadhyaksha, Memorial Sloan-Kettering Cancer Center, USA

4. Andrew Dunn, University of Texas, USA

5. Sava Sakadzic, Massachusetts General Hospital, Harvard Medical School, USA
6. Andrew Rollins, Case Western Reserve University, USA

7. Wiendelt Steenbergen, University of Twente, The Netherlands

8. Mengxing Tang, Imperial College London, United Kingdom

9. Shuliang Jiao, Florida International University, USA

10. Guoqiang Yu, University of Kentucky, USA

Finally, we are especially grateful to the following top 10 reviewers who reviewed the most papers in the year of 2012:

1. Yi Yang, University of Connecticut, USA

2. Yu Chen, University of Maryland, USA

3. Baohong Yuan, University of Texas at Arlington, USA

4. Kirill Larin, University of Houston, USA

5. Yu Shang, University of Kentucky, USA

6. Stephen Kanick, Dartmouth College, USA

7. Igor Meglinski, University of Otago, New Zealand

8. Jonathan Liu, State University of New York, Stony Brook, USA

9. Murat Canpolat, Akdeniz University, Turkey

10. Alexey Bashkatov, Saratov State University, Russian Federation

To manage our manuscripts more efficiently, we have appointed Ricky Wang as the Letters Editor, Stefan Andersson-Engels as the Reviews Editor, and Bob Alfano as the Technical Notes Editor. Please feel free to contact them regarding the corresponding types of manuscripts. Their contact information can be found at http:// spie.org/jbo.

As always, I welcome any suggestions for improving JBO and look forward to working with you.

Lihong V. Wang Editor-in-Chief 